\title{
IL-6 and IL-10 gene polymorphisms and cirrhosis of liver risk from a comprehensive analysis
}

Minghui Zheng ${ }^{1,2+}$, Weizhen Fang ${ }^{1,2+}$, Menglei Yu ${ }^{2,3+}$, Rui Ding ${ }^{1,2}$, Hua Zeng ${ }^{1,2}$, Yan Huang ${ }^{4,5^{*}}$, Yuanyang Mi ${ }^{6^{*}}$ and Chaohui Duan ${ }^{1,2^{*}}$

\begin{abstract}
Background: Different inflammatory and immune cytokines play a key role in the development of cirrhosis of liver $(\mathrm{CL})$. To investigate the association between interleukin-6,10 (IL-6,10) genes polymorphisms and $\mathrm{CL}$ risk through comparison of the allele and genotype distribution frequencies by meta-analysis.

Methods: A literature search covered with the PubMed, Embase, Cochrane Library, Web of Science, Google Scholar, SinoMed (CNKI and Wanfang) through 20th April, 2021. Odds ratios (OR) and 95\% confidence intervals (Cl) were used to assess the strength of associations.

Results: After a comprehensive search, three common polymorphisms (rs1800872, rs1800871, rs1800896) in IL-10 gene were selected, and three common polymorphisms (rs1800795, rs1800796, rs 1800797) in IL-6 gene were also identified. The important finding was that IL-10 rs 1800872 was a risk factor for $C L$ development. For example, there has a significantly increased relationship between rs1800872 polymorphism and CL both in the whole group (OR: 1.30, 95\% Cl: 1.01-1.67 in heterozygote model), Asian population (OR: 1.40, 95\% Cl: 1.03-1.88 in heterozygote model) and hospital-based source of control (OR: 1.40, 95\% Cl: 1.01-1.96 in dominant model). In addition, significant association was found between rs1800896 and primary biliary cirrhosis subtype disease (OR: 1.30, 95\%Cl: 1.01-1.68 in allelic contrast model). No association was observed in all three polymorphisms in IL-6 gene.
\end{abstract}

Conclusion: Our present study suggests that the IL-10 rs1800872 and rs1800896 polymorphisms is potentially associated with the risk of $\mathrm{CL}$ susceptibility.

Keywords: Interleukin-10, Interleukin-6, Cirrhosis of liver, Polymorphism, meta-analysis, Risk

\footnotetext{
*Correspondence: 9358369@qq.com; miniao1984@163.com;

1725012289@qq.com

${ }^{\dagger}$ Minghui Zheng, Weizhen Fang and Menglei Yu contributed equally to this

work.

${ }^{4}$ Department of Parasitology, Zhongshan School of Medicine, Sun Yat-sen

University, Guangzhou, Guangdong 510080, People's Republic of China

${ }^{6}$ Department of Urology, Affiliated Hospital of Jiangnan University, 1000

Hefeng Rd, Wuxi 214000, People's Republic of China

'Department of Clinical Laboratory, Sun Yat-sen Memorial Hospital of Sun

Yat-sen University, Guangzhou 510120, China

Full list of author information is available at the end of the article
}

C C The Author(s). 2021 Open Access This article is licensed under a Creative Commons Attribution 4.0 International License, which permits use, sharing, adaptation, distribution and reproduction in any medium or format, as long as you give appropriate credit to the original author(s) and the source, provide a link to the Creative Commons licence, and indicate if changes were made. The images or other third party material in this article are included in the article's Creative Commons licence, unless indicated otherwise in a credit line to the material. If material is not included in the article's Creative Commons licence and your intended use is not permitted by statutory regulation or exceeds the permitted use, you will need to obtain permission directly from the copyright holder. To view a copy of this licence, visit http://creativecommons.org/licenses/by/4.0/. The Creative Commons Public Domain Dedication waiver (http://creativecommons.org/publicdomain/zero/1.0/) applies to the data made available in this article, unless otherwise stated in a credit line to the data. 


\section{Background}

Cirrhosis is characterized by extreme liver scarring (fibrosis), loss of organ function and serious complications related to portal hypertension (high blood pressure in the hepatic portal vein and its branches) [1].

Cirrhosis is the 11th leading cause of death worldwide, with a total burden of about 123 million deaths, of which about one tenth is decompensated [2,3]. Liver cirrhosis (LC) is a severe public health problem worldwide, which is correlated with higher morbidity and mortality $[4,5]$. The most common causes were chronic viral hepatitis [including infectious Hepatitis B virus (HBV, 39.64 million), and infectious Hepatitis $\mathrm{C}$ virus (HCV, 30.36 million)], alcoholic liver disease (26.04 million) and nonalcoholic fatty liver disease (NAFLD, 10.26 million), and other causes (16.62 million) [6]. With the implementation of HBV vaccination program and the application of effective anti HBV and $\mathrm{HCV}$ drugs in high endemic areas, the rate of liver cirrhosis caused by hepatitis gradually decreased, and the number of cases caused by NAFLD gradually increased [7]. NAFLD is now the commonest etiology worldwide, affecting 1 in 4 adults [8], and the progressive form that leads to patient with NAFLD, is predicted to increase by 63\% between 2015 and 2030, representing a global cohort of at least 100 million individuals [9].

In the absence of effective intervention, cirrhosis can progress to decompensation, with ascites, gastrointestinal bleeding, hepatic encephalopathy, hepatorenal syndrome, and liver cancer [7]. Liver transplantation is the most effective therapeutic option for end-stage liver disease but is a scarce resource [1]. Moreover, although antifibrotic or proregenerative drug therapies for cirrhosis have been approved, they have been in clinical trials and the effect has not been determined [1].

Cytokines, such as interleukins, play an integral role in the host immune response and may be a critical factor in determining the duration and severity of virus infection, fibrosis formation $[10,11]$. Interleukin-10 (IL-10) is an important anti-inflammatory cytokine secreted by different cells such as liver cells, $\mathrm{T}$ regulatory lymphocytes, activated macrophages, and $\mathrm{T}$ helper (Th) 2 cells [12]. It inhibits macrophage-dependent antigen presentation, proliferation of T-lymphocytes, and Th1 cytokine secretion and acts as an inhibitor of Th1 effectors mechanism [12]. Three common polymorphisms -1082G/A (rs1800896), $-819 \mathrm{C} / \mathrm{T}$ (rs1800871), and $-592 \mathrm{C} / \mathrm{A}$ (rs1800872) related to cirrhosis of liver (CL) have been wildly reported [13]. IL-6, a primary immunomodulatory cytokine, has been documented to play a pivotal role in regulating the biological processes of many cells including hepatocytes [14]. Three common polymorphisms -174G/ C (rs1800795), - 572G/C (rs1800796), and - 597 G/A (rs1800797) related to CL have been wildly reported [15].
In order to overcome the factors of sample size, regional and ethnic differences, our study summarized all published literatures related to the relationship between IL- 6 and IL-10genes polymorphisms and CL by metaanalysis, to comprehensively evaluate the relationship between several polymorphisms and CL, and to provide evidence-based medical research basis for the etiology of CL.

\section{Materials and methods}

\section{Literature search strategy}

A computerized literature search was performed for relevant studies from PubMed, Embase, Cochrane Library, Web of Science, Google Scholar, SinoMed (CNKI and Wanfang) before 20th April, 2021. The following keywords were jointly used "interleukin 10 or interleukin 6 or IL-10 or IL-6", "polymorphism or variation or mutation", "rs1800795 or rs1800796 or rs1800797 or rs1800896 or rs1800871 or rs1800872" and "live cirrhosis or primary biliary cirrhosis or nonalcoholic fatty liver disease". If studies applied the same case clinic information, only the largest sample size was selected [16].

\section{Inclusion criteria}

The included studies met the following criteria: (a) there were clear criteria for the diagnosis of $\mathrm{CL}$, such as B-ultrasound, CT, MRI, endoscopic retrograde cholangiopancreatography, liver biopsy, and so on, (b) the correlation between CL risk and IL-10 and IL- 6 genes polymorphisms (rs1800795 or rs1800796 or rs1800797 or rs1800896 or rs1800871 or rs1800872), (c) casecontrol or cohort design, (d) provided sufficient data for calculating odds ratio (OR) with $95 \%$ confidence interval $(95 \% \mathrm{CI})$, and (e) duplicated studies with the same cases [17].

\section{Data extraction}

The following information was extracted from each included study: name of the first author, publication year, country of origin, ethnicity, numbers of cases and controls, HWE of control group, genotype method and sub-type of CL. The data were selected independently by 2 investigators who reached a consensus on all items [18].

\section{Statistical analysis}

The associations of the IL-10 and IL- 6 genes polymorphisms and risk of CL were estimated by calculating the OR and $95 \% \mathrm{CI}$. The statistical significance of the OR was determined with the $Z$ test [19]. The significance of the effect for correlation was determined by the $Z$ test [18]. The heterogeneity among studies was evaluated using a Q test and $I^{2}$ test as described in other studies 
$[20,21]$. As a guide, $I^{2}$ values of $<25 \%$ may be considered 'low', value of $\sim 50 \%$ may be considered 'moderate' and values of $>75 \%$ may be considered 'high' [22]. The Mantel-Haenszel (fixed effect) model was chosen, otherwise, if $P_{\text {heterogeneity }}<0.1$, the random effects (DerSimonian-Laird) model was applied [23, 24]. Sensitivity analysis was undertaken by removing each study once to assess whether any single study could influence the stability of results [25]. The departure of frequencies of six polymorphisms from expectation under HWE was assessed by the Pearson's $X^{2}$ test, $P<0.05$ was considered significant [26]. Begg's funnel plots and Egger's regression test were performed to estimate the potential publication bias [27]. All statistical tests for this meta-analysis were performed using version 10.0 Stata software (StataCorp LP, College Station, TX, USA) [18].

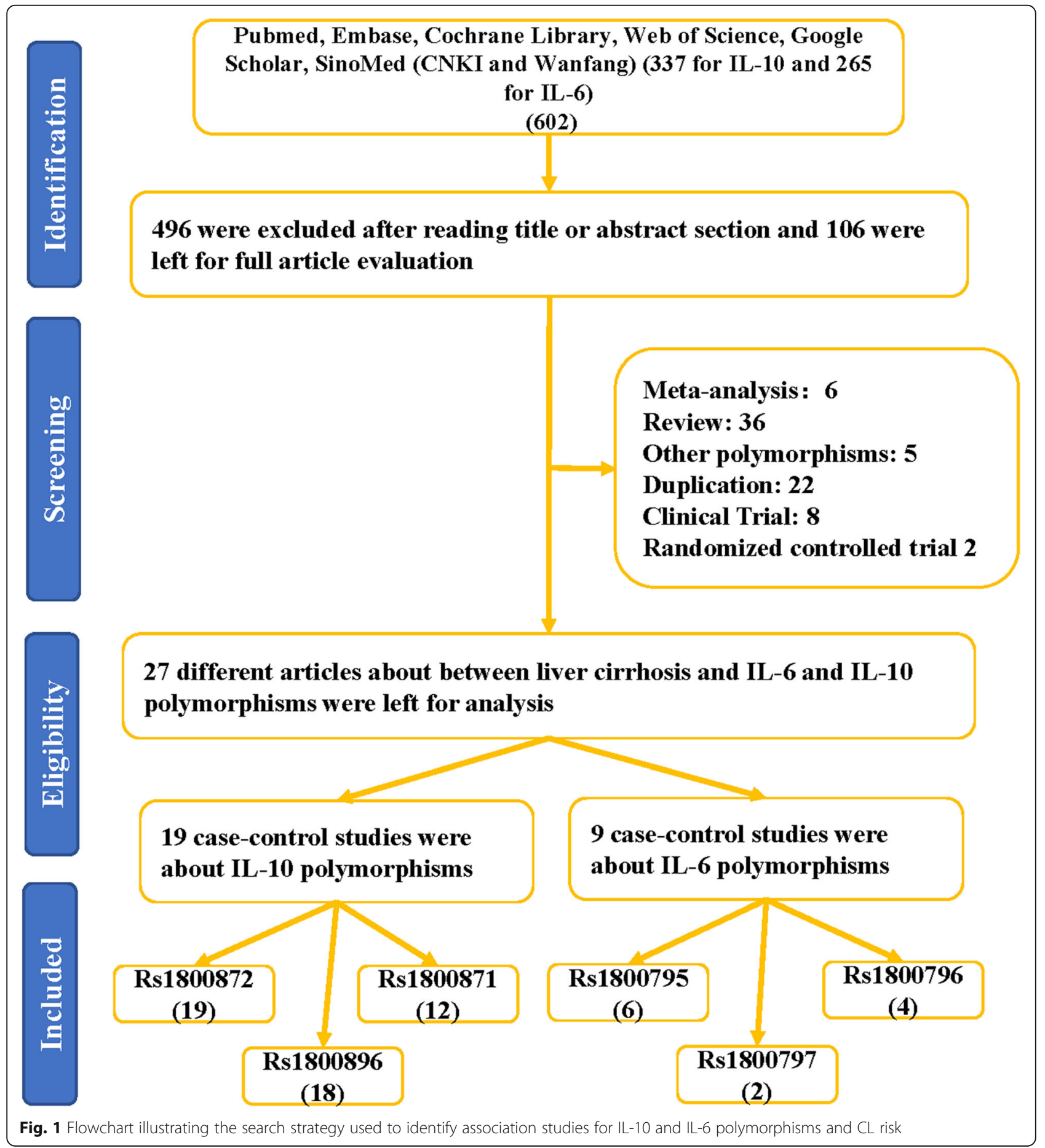


Table 1 Characteristics of included studies about polymorphisms in IL-6 and IL-10 genes and cirrhosis of liver risk

\begin{tabular}{|c|c|c|c|c|c|c|c|c|c|}
\hline Author & Year & Country & Ethnicity & Case & Control & SOC & HWE & Genotype & Sub-type \\
\hline-592 & \multicolumn{9}{|c|}{ rs1800872 } \\
\hline Chen & 2004 & China & Asian & 77 & 54 & $H B$ & 0.633 & PCR-RFLP & PBC \\
\hline Zappala & 1998 & UK & Caucasian & 171 & 141 & $H B$ & 0.071 & $P C R$ & PBC \\
\hline Matsushita & 2002 & USA & Caucasian & 94 & 72 & PB & 0.501 & PCR-RFLP & PBC \\
\hline Matsushita & 2002 & USA & Caucasian & 65 & 71 & PB & $<0.01$ & PCR-RFLP & PBC \\
\hline Marcos & 2008 & Spain & Caucasian & 96 & 100 & $H B$ & 0.093 & PCR-RFLP & $\mathrm{ALC}$ \\
\hline Yao & 2015 & China & Asian & 318 & 318 & PB & $<0.01$ & PCR-RFLP & LC \\
\hline Barooah & 2020 & India & Asian & 96 & 110 & $\mathrm{HB}$ & 0.009 & PCR-RFLP & HCV-LC \\
\hline Liu & 2015 & China & Asian & 192 & 192 & $H B$ & $<0.01$ & Sequenom Assay Design & Mixed \\
\hline Cao & 2016 & China & Asian & 241 & 254 & $\mathrm{HB}$ & $<0.01$ & PCR-RFLP & LC \\
\hline Baghi & 2015 & Iran & Asian & 9 & 102 & PB & 0.664 & PCR-RFLP & HBV-LC \\
\hline Cheong & 2005 & South Korea & Asian & 79 & 261 & $\mathrm{HB}$ & $<0.01$ & $P C R$ & HBV-LC \\
\hline Sheneef & 2017 & Egypt & African & 50 & 50 & PB & 0.889 & ARMS-PCR & HCV-LC \\
\hline Corchado & 2013 & Korea & Asian & 39 & 49 & $\mathrm{HB}$ & 0.187 & $P C R$ & HCV-LC \\
\hline Fan & 2004 & China & Asian & 77 & 160 & $H B$ & $<0.01$ & PCR-RFLP & PBC \\
\hline Khalifa & 2016 & Saudi Arabia & Asian & 109 & 110 & $\mathrm{HB}$ & 0.525 & PCR-RFLP & HBV-LC \\
\hline Moreira & 2016 & Brazil & Mixed & 37 & 102 & $H B$ & 0.316 & PCR-SSP & HCV-LC \\
\hline Wang & 2010 & China & Asian & 50 & 42 & $\mathrm{HB}$ & $<0.01$ & PCR & HBV-LC \\
\hline Jiang & 2009 & China & Asian & 169 & 119 & $\mathrm{HB}$ & 0.552 & PCR-RFLP & HBV-LC \\
\hline Wu & 2010 & China & Asian & 50 & 96 & $H B$ & 0.125 & PCR-RFLP & HBV-LC \\
\hline-819 & \multicolumn{9}{|c|}{ rs1800871 } \\
\hline Chen & 2004 & China & Asian & 77 & 54 & $H B$ & 1 & PCR-RFLP & PBC \\
\hline Matsushita & 2002 & USA & Caucasian & 94 & 72 & PB & 0.501 & PCR-RFLP & PBC \\
\hline Matsushita & 2002 & USA & Caucasian & 65 & 71 & PB & 0.049 & PCR-RFLP & PBC \\
\hline Yao & 2015 & China & Asian & 318 & 318 & PB & 0.227 & PCR-RFLP & LC \\
\hline Barooah & 2020 & India & Asian & 96 & 110 & $\mathrm{HB}$ & 0.474 & PCR-RFLP & HCV-LC \\
\hline Liu & 2015 & China & Asian & 192 & 192 & $\mathrm{HB}$ & 0.073 & Sequenom Assay Design & Mixed \\
\hline Baghi & 2015 & Iran & Asian & 9 & 102 & PB & 0.369 & PCR-RFLP & HBV-LC \\
\hline Cheong & 2005 & South Korea & Asian & 79 & 261 & $\mathrm{HB}$ & 0.458 & $P C R$ & HBV-LC \\
\hline Yang & 2013 & China & Asian & 40 & 64 & PB & 0.821 & ARMS-PCR & $\mathrm{ALC}$ \\
\hline Fan & 2004 & China & Asian & 77 & 160 & $H B$ & 0.455 & PCR-RFLP & PBC \\
\hline Moreira & 2016 & Brazil & Mixed & 37 & 102 & $H B$ & 0.316 & PCR-SSP & HCV-LC \\
\hline Wang & 2010 & China & Asian & 50 & 43 & $\mathrm{HB}$ & 0.017 & PCR & HBV-LC \\
\hline-1082 & \multicolumn{9}{|c|}{ rs1800896 } \\
\hline Chen & 2004 & China & Asian & 77 & 54 & $\mathrm{HB}$ & 0.611 & PCR-RFLP & PBC \\
\hline Bathgate & 2000 & UK & Caucasian & 61 & 330 & $H B$ & 0.003 & sequence & PBC \\
\hline Matsushita & 2002 & USA & Caucasian & 94 & 72 & PB & 0.859 & PCR-RFLP & PBC \\
\hline Matsushita & 2002 & USA & Caucasian & 65 & 71 & PB & 0.568 & PCR-RFLP & PBC \\
\hline Abd El-Baky & 2020 & Egypt & African & 22 & 48 & PB & $<0.01$ & TaqMan real-time PCR & HCV-LC \\
\hline Yao & 2015 & China & Asian & 318 & 318 & PB & 0.898 & PCR-RFLP & LC \\
\hline Barooah & 2020 & India & Asian & 96 & 110 & $\mathrm{HB}$ & 0.054 & PCR-RFLP & HCV-LC \\
\hline Liu & 2015 & China & Asian & 266 & 532 & $\mathrm{HB}$ & $<0.01$ & Sequenom Assay Design & Mixed \\
\hline Cao & 2016 & China & Asian & 241 & 254 & PB & 0.953 & PCR-RFLP & LC \\
\hline Baghi & 2015 & Iran & Asian & 9 & 102 & PB & 0.047 & PCR-RFLP & HBV-LC \\
\hline
\end{tabular}


Table 1 Characteristics of included studies about polymorphisms in IL-6 and IL-10 genes and cirrhosis of liver risk (Continued)

\begin{tabular}{|c|c|c|c|c|c|c|c|c|c|}
\hline Author & Year & Country & Ethnicity & Case & Control & SOC & HWE & Genotype & Sub-type \\
\hline Cheong & 2005 & South Korea & Asian & 79 & 261 & $\mathrm{HB}$ & 0.769 & $P C R$ & HBV-LC \\
\hline Yang & 2013 & China & Asian & 40 & 64 & PB & 0.452 & ARMS-PCR & $\mathrm{ALC}$ \\
\hline Sheneef & 2017 & Egypt & African & 50 & 50 & PB & 0.259 & ARMS-PCR & HCV-LC \\
\hline Fan & 2004 & China & Asian & 77 & 160 & $\mathrm{HB}$ & 0.505 & PCR-RFLP & PBC \\
\hline Khalifa & 2016 & Saudi Arabia & Asian & 109 & 110 & $\mathrm{HB}$ & 0.267 & PCR-RFLP & HBV-LC \\
\hline Moreira & 2016 & Brazil & Mixed & 37 & 102 & $\mathrm{HB}$ & 0.973 & PCR-SSP & HCV-LC \\
\hline Wang & 2010 & China & Asian & 50 & 42 & $H B$ & 0.874 & $P C R$ & HBV-LC \\
\hline Wu & 2010 & China & Asian & 50 & 96 & $\mathrm{HB}$ & 0.629 & PCR-RFLP & HBV-LC \\
\hline \multicolumn{10}{|l|}{$-174 G>C$} \\
\hline Giannitrapani & 2011 & Italy & Caucasian & 95 & 105 & $\mathrm{HB}$ & 0.776 & PCR-RFLP & LC \\
\hline Fan & 2004 & China & Asian & 77 & 160 & PB & $<0.01$ & SSP & $\mathrm{PBC}$ \\
\hline Falleti & 2008 & Italy & Caucasian & 219 & 236 & PB & 0.536 & PCR-RFLP & Mixed \\
\hline Marcos & 2009 & Spain & Caucasian & 96 & 160 & PB & 0.333 & TaqMan & $\mathrm{ALC}$ \\
\hline Motawi & 2016 & Egypt & African & 65 & 100 & $\mathrm{HB}$ & $<0.01$ & PCR-RFLP & HCV-LC \\
\hline Moreira & 2016 & Brazil & Mixed & 38 & 100 & $\mathrm{HB}$ & 0.718 & PCR-SSP & HCV-LC \\
\hline \multicolumn{10}{|l|}{ IL6-572 } \\
\hline Park & 2003 & Korea & Asian & 696 & 280 & PB & 0.193 & sequence & HBV-LC \\
\hline Falleti & 2008 & Italy & Caucasian & 219 & 236 & PB & 0.249 & PCR-RFLP & Mixed \\
\hline Saxenas & 2014 & India & Asian & 63 & 83 & $\mathrm{HB}$ & $<0.01$ & PCR-RFLP & HBV-LC \\
\hline Tang & 2013 & China & Asian & 153 & 265 & $\mathrm{HB}$ & 0.529 & TaqMan & HBV-LC \\
\hline \multicolumn{10}{|l|}{$597 G>A$} \\
\hline Falleti & 2008 & Italy & Caucasian & 219 & 236 & PB & 0.348 & PCR-RFLP & Mixed \\
\hline Saxenas & 2014 & India & Asian & 3 & 138 & $\mathrm{HB}$ & 0.613 & PCR-RFLP & HBV-LC \\
\hline
\end{tabular}

HB: hospital-based; PB: population-based; SOC; source of control; PCR-RFLP: polymerase chain reaction followed by restriction fragment length polymorphism; SSP: sequence specific primer; ARMS: amplification refractory mutation system; HWE: Hardy-Weinberg equilibrium of control group; PBC: primary biliary cirrhosis; LC: liver cirrhosis; ALC: alcoholic liver cirrhosis, HCV: hepatitis C virus infection, HBV: hepatitis B virus infection

\section{Network of protein-interaction of IL- 6 and IL-10 gene}

To more complete understanding of the role of IL-6 and IL-10 in CL, the network of gene-gene interactions for IL-6 and IL-10 was predicted through online String database (http://string-db.org/) [28].

\section{Results}

\section{Study searching and their basic information}

As depicted in Fig. 1, 602 articles were garnered by PubMed, Embase, Cochrane Library, Web of Science, Google Scholar, SinoMed (CNKI and Wanfang (337 titles about IL-10 gene polymorphisms and 265 titles for IL-6 gene polymorphisms) database. 496 obviously irrelevant articles were excluded after screening the titles and abstract sections. The full texts were then evaluated, and 79 additional articles were further excluded as they were duplication (22), meta-analysis systematic analysis or review (42), other polymorphisms (5), clinical trial (8) and randomized controlled trial (2). Finally, 27 different articles [15, 29-55] met the inclusion criteria and were included in our meta-analysis. Among these included studies, 19 studies were performed about IL-10 three polymorphisms (19 case-control studies for rs1800872, 12 for rs1800871, 18 for rs1800896), and 9 studies was related to IL-6 three polymorphisms ( 6 for rs1800795, 4 for 1,800,796 and 2 for rs1800797). All the included studies used blood samples for DNA extraction (Table 1). In addition, we checked the Minor Allele Frequency (MAF) reported for the six main worldwide populations in the 1000 Genomes Browser (https://www.ncbi.nlm. nih.gov/snp/) (Fig. 2). The genotyping methods included polymerase chain reaction-restrictive fragment length polymorphism, sequencing, TaqMan, Sequenom Assay Design, amplification refractory mutation system and sequence specific primer.

\section{Quantitative synthesis}

\section{IL-10 - 592 polymorphism}

In whole analysis, increased associations were observed in two genetic models (heterozygote comparison: OR: $1.30, \quad 95 \% \mathrm{CI}: 1.01-1.67, \quad P=0.006$ for heterogeneity, $P=0.039, I^{2}=50.9 \%$, Fig. $3 \mathrm{~A}$; dominant 


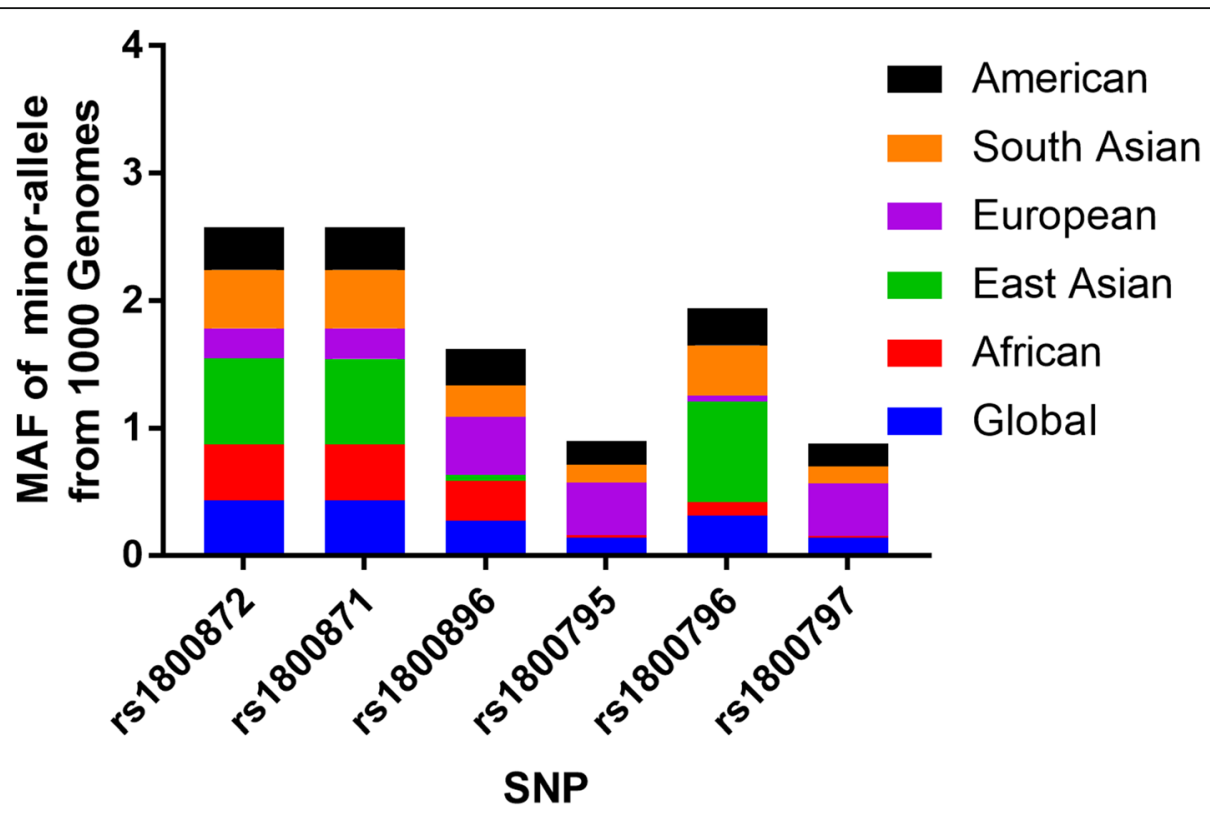

Fig. 2 The MAF of minor-allele (mutant-allele) for IL-10 and IL-6 polymorphisms from the 1000 Genomes online database and present analysis

model: OR: 1.34, 95\%CI:1.04-1.72, $P=0.001$ for heterogeneity, $\left.P=0.021, I^{2}=57.5 \%\right)$. In subgroup analysis by ethnicity, based on different frequency of races, there also had increased associations between this polymorphism and CL in Asians not Caucasians in all models (allelic contrast: OR: 1.25, 95\%CI:1.01-1.55, $P=0.000$ for heterogeneity, $P=0.042, I^{2}=72.3 \%$; heterozygote comparison: OR: $1.40,95 \% \mathrm{CI}: 1.03-1.88, P=$ 0.001 for heterogeneity, $P=0.029, I^{2}=63.1 \%$, Fig. 3A; dominant model: OR: 1.47, 95\%CI:1.09-1.99, $P=0.000$ for heterogeneity, $\left.P=0.013, I^{2}=68.3 \%\right)$. In addition, regular analysis by source of control, also significantly trend was found for this SNP in $\mathrm{HB}$ rather than $\mathrm{PB}$ studies (dominant model: OR: 1.40, 95\%CI:1.01-1.96, $P=0.000$ for heterogeneity, $P=0.046, I^{2}=68.2 \%$, Fig. 3B). Finally, many causes may result in cirrhosis, such as primary biliary cirrhosis (PBC), alcoholics with liver cirrhosis, HCV-LC, HBV-LC and immune
A

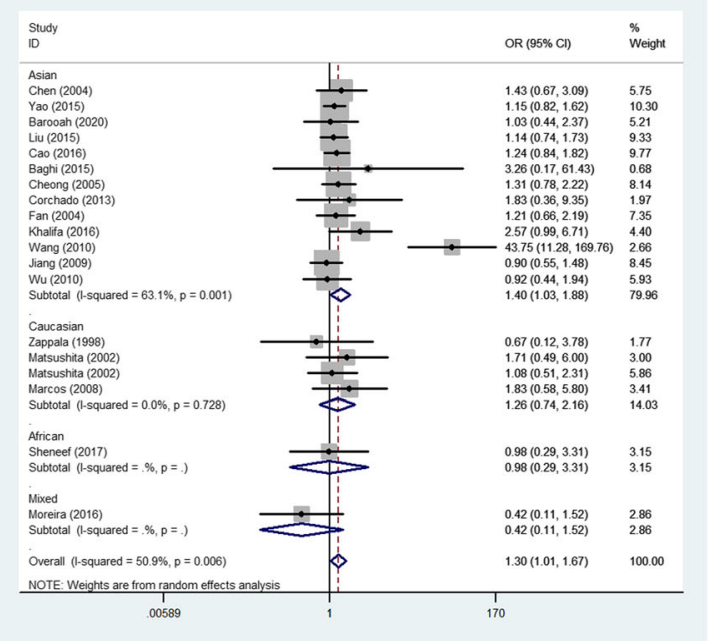

B

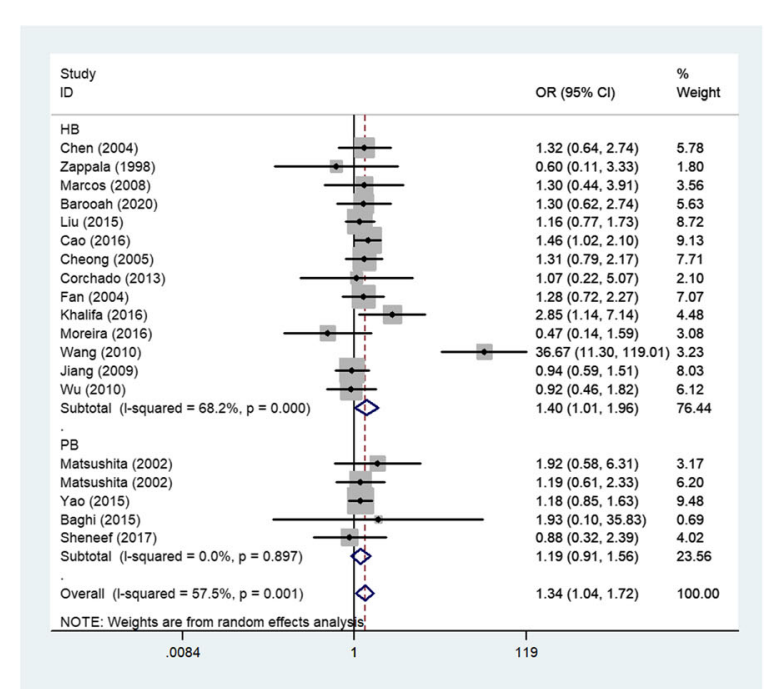

Fig. 3 Forest plot of $\mathrm{CL}$ risk associated with IL-10 gene -592 polymorphism A: heterozygote comparison model in total analysis and in ethnicity subgroup; B: dominant model in source of control 
Table 2 Stratified analyses of IL-6 and IL-10 genes' common polymorphisms on cirrhosis of liver risk

\begin{tabular}{|c|c|c|c|c|c|}
\hline Variables & $\mathrm{N}$ & Case/ & Allelic contrast & Heterozygote comparison & Dominant model \\
\hline & & Control & $\mathrm{OR}(95 \% \mathrm{Cl}) P_{\mathrm{h}} P$ l-squared & $\mathrm{OR}(95 \% \mathrm{Cl}) P_{\mathrm{h}} P$-squared & OR(95\%Cl) $P_{\mathrm{h}} P$ l-squared \\
\hline \multicolumn{6}{|l|}{ IL-10 -592 } \\
\hline Total & 19 & $2019 / 2403$ & $1.15(0.98-1.37) 0.0000 .09365 .7 \%$ & $1.30(1.01-1.67) 0.0060 .03950 .9 \%$ & $1.34(1.04-1.72) 0.0010 .02157 .5 \%$ \\
\hline \multicolumn{6}{|l|}{ Ethnicity } \\
\hline Asian & 13 & $1506 / 1867$ & $1.25(1.01-1.55) 0.0000 .04272 .3 \%$ & 1.40 (1.03-1.88)0.001 0.02963.1\% & $1.47(1.09-1.99) 0.0000 .01368 .3 \%$ \\
\hline Caucasian & 4 & $426 / 384$ & $0.98(0.78-1.22) 0.2700 .84023 .4 \%$ & $1.26(0.74-2.14) 0.7280 .3990 .0 \%$ & $1.24(0.76-2.02) 0.7470 .3950 .0 \%$ \\
\hline \multicolumn{6}{|l|}{ SOC } \\
\hline $\mathrm{HB}$ & 14 & $1483 / 1790$ & $1.19(0.95-1.48) 0.0000 .12573 .6 \%$ & 1.36 (0.98-1.89)0.001 0.06863.5\% & $1.40(1.01-1.96) 0.0000 .04668 .2 \%$ \\
\hline PB & 5 & $536 / 613$ & $1.11(0.93-1.33) 0.5940 .2340 .0 \%$ & $1.17(0.88-1.57) 0.9170 .2770 .0 \%$ & $1.19(0.91-1.56) 0.8970 .2080 .0 \%$ \\
\hline \multicolumn{6}{|c|}{ Disease type } \\
\hline PBC & 5 & $484 / 498$ & $1.11(0.91-1.35) 0.5900 .3190 .0 \%$ & $1.23(0.85-1.78) 0.9080 .2810 .0 \%$ & $1.27(0.89-1.79) 0.8710 .1840 .0 \%$ \\
\hline HBV-LC & 6 & $466 / 730$ & $1.46(0.86-2.49) 0.0000 .16335 .9 \%$ & $2.24(0.95-5.28) 0.0000 .06584 .0 \%$ & $2.26(0.95-5.38) 0.0000 .06586 .3 \%$ \\
\hline HCV-LC & 4 & $222 / 311$ & $0.98(0.75-1.28) 0.1610 .90141 .8 \%$ & $0.93(0.53-1.64) 0.5310 .7940 .0 \%$ & $0.98(0.59-1.62) 0.5720 .9260 .0 \%$ \\
\hline \multicolumn{6}{|l|}{-819} \\
\hline Total & 12 & $1134 / 1549$ & $1.07(0.88-1.30) 0.0170 .48552 .4 \%$ & $1.14(0.86-1.51) 0.0720 .35440 .3 \%$ & $1.15(0.86-1.53) 0.0290 .35448 .8 \%$ \\
\hline \multicolumn{6}{|l|}{ Ethnicity } \\
\hline Asian & 9 & 938/1304 & $1.05(0.82-1.34) 0.0060 .08963 .0 \%$ & 1.18 (0.86-1.64)0.047 0.30449.0\% & $1.17(0.83-1.64) 0.0160 .36757 .2 \%$ \\
\hline Caucasian & 2 & $159 / 143$ & $1.28(0.90-1.83) 0.7900 .1730 .0 \%$ & $1.23(0.64-2.34) 0.5420 .5370 .0 \%$ & $1.33(0.74-2.39) 0.4930 .3340 .0 \%$ \\
\hline \multicolumn{6}{|l|}{ SOC } \\
\hline $\mathrm{HB}$ & 7 & $608 / 922$ & $1.14(0.88-1.47) 0.0370 .32155 .2 \%$ & $1.22(0.78-1.91) 0.0200 .38660 .2 \%$ & $1.23(0.80-1.91) 0.0160 .34361 .5 \%$ \\
\hline PB & 5 & $526 / 627$ & $0.96(0.68-1.36) 0.0450 .83258 .9 \%$ & $1.07(0.81-1.42) 0.5430 .6140 .0 \%$ & $1.08(0.83-1.40) 0.2290 .55628 .8 \%$ \\
\hline \multicolumn{6}{|c|}{ Disease type } \\
\hline PBC & 4 & $313 / 357$ & $1.24(0.97-1.57) 0.9640 .0820 .0 \%$ & $1.37(0.95-1.99) 0.9060 .0950 .0 \%$ & $1.38(0.97-1.96) 0.9110 .0710 .0 \%$ \\
\hline HBV-LC & 3 & $138 / 406$ & $1.55(0.55-4.43) 0.0040 .40981 .6 \%$ & $2.96(0.70-12.47) 0.0320 .14070 .8 \%$ & $2.68(0.67-10.74) 0.0240 .16573 .2 \%$ \\
\hline HCV-LC & 2 & $133 / 212$ & $0.92(0.66-1.27) 0.9010 .5950 .0 \%$ & $0.65(0.38-1.14) 0.4570 .1320 .0 \%$ & $0.71(0.42-1.20) 0.4670 .2030 .0 \%$ \\
\hline \multicolumn{6}{|l|}{-1082} \\
\hline Total & 18 & $1741 / 2776$ & $1.01(0.85-1.20) 0.0130 .89247 .5 \%$ & $1.01(0.82-1.23) 0.2020 .94121 .2 \%$ & $1.00(0.80-1.24) 0.0530 .97137 .9 \%$ \\
\hline \multicolumn{6}{|l|}{ Ethnicity } \\
\hline Asian & 12 & $1412 / 2103$ & $0.94(0.76-1.17) 0.0180 .57751 .9 \%$ & $1.01(0.78-1.33) 0.0920 .92137 .5 \%$ & $0.96(0.72-1.29) 0.0240 .79550 .2 \%$ \\
\hline Caucasian & 3 & $220 / 473$ & $1.25(0.94-1.65) 0.3230 .12211 .4 \%$ & $1.20(0.78-1.85) 0.9000 .4090 .0 \%$ & $1.30(0.86-1.95) 0.6990 .2130 .0 \%$ \\
\hline African & 2 & $72 / 98$ & $1.27(0.82-1.97) 0.8170 .2820 .0 \%$ & $1.12(0.47-2.70) 0.2410 .79927 .2 \%$ & $1.24(0.55-2.82) 0.2690 .60218 .0 \%$ \\
\hline \multicolumn{6}{|l|}{ SOC } \\
\hline $\mathrm{HB}$ & 10 & $902 / 1797$ & $1.04(0.89-1.21) 0.5020 .6010 .0 \%$ & $1.11(0.90-1.37) 0.7340 .3190 .0 \%$ & $1.09(0.90-1.32) 0.6830 .3800 .0 \%$ \\
\hline PB & 8 & $839 / 979$ & $0.99(0.72-1.36) 0.0050 .96665 .8 \%$ & $0.86(0.56-1.33) 0.0870 .50543 .7 \%$ & $0.87(0.53-1.42) 0.0160 .57759 .3 \%$ \\
\hline \multicolumn{6}{|c|}{ Disease type } \\
\hline PBC & 5 & $374 / 687$ & $1.30(1.01-1.68) 0.5680 .0430 .0 \%$ & $1.32(0.93-1.89) 0.9010 .1220 .0 \%$ & $1.39(0.98-1.95) 0.8630 .0610 .0 \%$ \\
\hline HBV-LC & 5 & $297 / 611$ & $0.97(0.71-1.32) 0.3180 .82715 .2 \%$ & $1.30(0.89-1.90) 0.5270 .1700 .0 \%$ & $1.15(0.80-1.67) 0.4200 .4470 .0 \%$ \\
\hline HCV-LC & 4 & $205 / 310$ & $0.98(0.76-1.28) 0.5470 .8970 .0 \%$ & $0.81(0.53-1.24) 0.8650 .3320 .0 \%$ & $0.85(0.58-1.26) 0.4890 .4140 .0 \%$ \\
\hline LC & 2 & $559 / 572$ & $0.72(0.60-0.85) 0.9870 .0000 .0 \%$ & $0.64(0.44-0.93) 0.8650 .0190 .0 \%$ & $0.56(0.39-0.80) 0.8920 .0010 .0 \%$ \\
\hline \multicolumn{6}{|l|}{ IL-6 -174 } \\
\hline Total & 6 & $590 / 861$ & $1.17(0.73-1.86) 0.0020 .51177 .5 \%$ & $1.42(0.70-2.87) 0.0000 .33078 .3 \%$ & $1.37(0.71-2.63) 0.0010 .34677 .2 \%$ \\
\hline \multicolumn{6}{|l|}{ Ethnicity } \\
\hline Caucasian & 3 & $410 / 501$ & $0.89(0.73-1.09) 0.6310 .2440 .0 \%$ & $0.87(0.65-1.15) 0.3140 .31613 .7 \%$ & $0.86(0.66-1.12) 0.5500 .2570 .0 \%$ \\
\hline SOC & & & & & \\
\hline
\end{tabular}


Table 2 Stratified analyses of IL-6 and IL-10 genes' common polymorphisms on cirrhosis of liver risk (Continued)

\begin{tabular}{|c|c|c|c|c|c|}
\hline Variables & $\mathrm{N}$ & Case/ & Allelic contrast & Heterozygote comparison & Dominant model \\
\hline $\mathrm{HB}$ & 3 & $198 / 305$ & $1.98(0.55-7.05) 0.0010 .29486 .8 \%$ & $2.79(0.41-18.88) 0.0000 .29490 .4 \%$ & $2.71(0.47-15.57) 0.0000 .26589 .6 \%$ \\
\hline PB & 3 & $392 / 556$ & $0.99(0.63-1.55) 0.0830 .96159 .8 \%$ & $1.04(0.76-1.42) 0.1300 .80050 .9 \%$ & $0.98(0.73-1.32) 0.1100 .91654 .7 \%$ \\
\hline \multicolumn{6}{|l|}{-572} \\
\hline Total & 4 & $1131 / 864$ & $1.15(0.97-1.36) 0.8590 .1170 .0 \%$ & $2.23(0.80-6.21) 0.0000 .12789 .2 \%$ & $1.60(0.83-3.06) 0.0050 .15776 .3 \%$ \\
\hline \multicolumn{6}{|l|}{-597} \\
\hline Total & 2 & $280 / 374$ & $0.84(0.66-1.08) 0.4530 .1680 .0 \%$ & $0.88(0.63-1.23) 0.2030 .46238 .3 \%$ & $0.84(0.61-1.15) 0.2780 .28315 .0 \%$ \\
\hline
\end{tabular}

$P_{\mathrm{h}}$ : value of $Q$-test for heterogeneity test; $P$ : $Z$-test for the statistical significance of the $\mathrm{OR}$

cirrhosis, to our regret, no significant association was found in all kinds of this subgroup (Table 2).

\section{IL-10 -1082 polymorphism}

No association was detected in total, ethnicity, source of control subgroups, however, in the subgroup of disease type subgroup, increased relationship was observed in the allelic contrast model (OR: 1.30, 95\%CI:1.01-1.68, $P=0.568$ for heterogeneity, $P=0.043, I^{2}=0.0 \%$ ) (Fig. 4A). In the sub-type of $\mathrm{CL}$, we found decreased association was existed in $\mathrm{LC}$ risk and this polymorphism (such as OR: 0.64, 95\%CI:0.44-0.93, $P=0.865$ for heterogeneity, $P=$ $0.019, I^{2}=0.0 \%$, Fig. $\left.4 \mathrm{~B}\right)$.

\section{IL-10-819, IL-6 -174, - 572 and - 597 polymorphisms}

No association was found in above four kinds of polymorphisms (data not shown) (Table 2).

\section{Bias diagnosis for publication and sensitivity analysis}

The publication bias was evaluated by both Begg's funnel plot and Egger's test (such as -592 polymorphism). At beginning, the shape of the funnel plots seemed asymmetrical in allele comparison for -592 by Begg's test, suggesting no publication bias was existed. Then, Egger's test was applied to provide statistical evidence of funnel plot symmetry. As a result, no obvious evidence of publication bias was observed (such as allelic contrast: $\mathrm{t}=2.57, P=0.024$ for Egger's test; $z=1.75, P=0.08$ for Begg's test (Fig. 5 A, B) (Table 3).

To delete studies which may influence the power and stability of whole study, we applied the sensitive analysis (such as -592 polymorphism), finally, no sensitive casecontrol studies were found for -592 SNP in three models (Fig. 5C).

\section{Gene-gene network diagram and interaction of online website}

String online server indicated that IL-10 and IL- 6 gene interacts with numerous genes. The network of genegene interaction has been illustrated in Fig. 6 .

\section{Discussion}

Cirrhosis is the final stage of liver fibrosis, which itself results from a perpetuated wound-healing process after a liver injury that can lead to a wide range of chronic

\section{A}

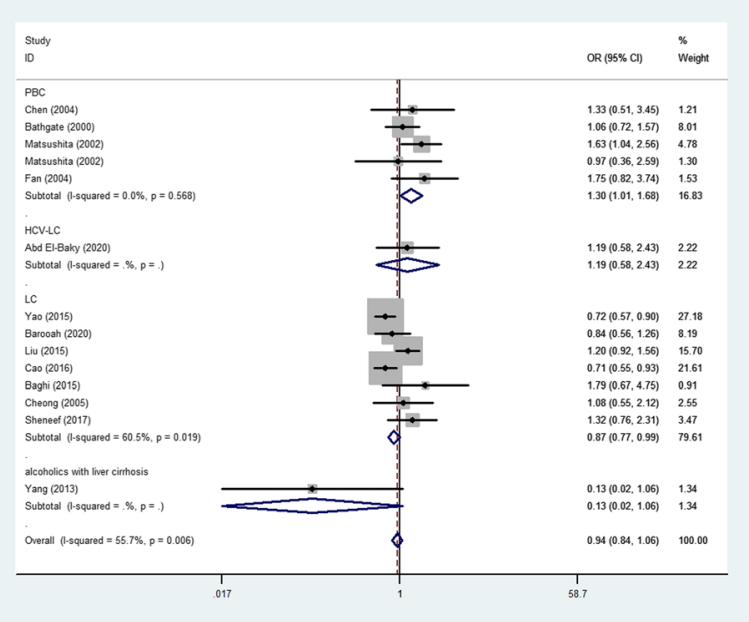

B

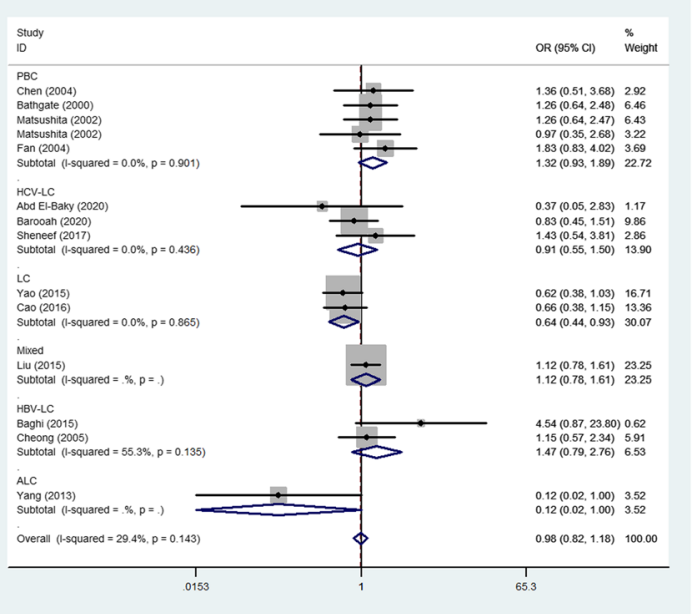

Fig. 4 Forest plot of $C L$ risk associated with IL-10 gene - 1082 polymorphism from allelic contrast in sub-type analysis. A: PBC in the allelic contrast model; B: LC in the allelic contrast model 


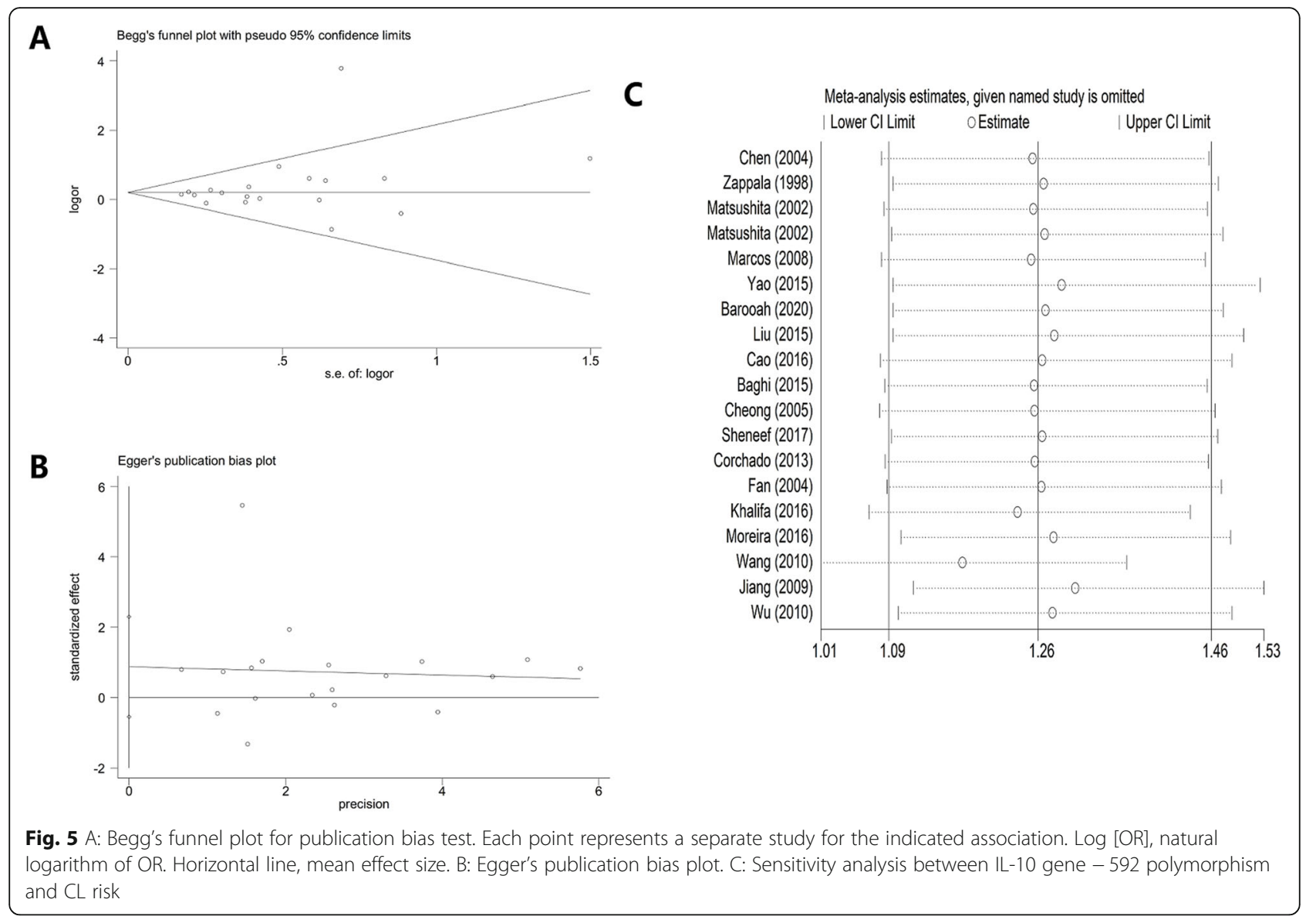

diseases involving the liver [56, 57]. In addition, cirrhosis is a burden on the individual and on public health. To our knowledge, the most prevalent chronic liver diseases are chronic viral hepatitis (from hepatitis B or C infection), alcohol-related liver disease, and NAFLD [56].

Cirrhosis negatively impacts on patient reported outcomes and health-related quality of life [58-60]. The impact of cirrhosis on quality of life can add to the existing impairment of quality of life related to viraemia in patients with hepatitis C [61, 62]. Conversely, effective treatment of hepatitis $\mathrm{C}$ can lead to significant gains in patients' quality of life, especially for patients with decompensated cirrhosis. In addition, there is evolving evidence indicating that quality of life is significantly impaired in patients with NAFLD in the form of nonalcoholic steatohepatitis [63]. Nowadays, the trends indicate that the contribution from NAFLD related cirrhosis is increasing within cirrhosis. Other risk factors, such as substantial regional variation, and substantial variation in time trends in the prevalence of these etiology, should also been paid attention.

We devoted to find some susceptible factors, finally, we focused on two cytokines (IL-6 and IL-10). So far, multiple genes have been shown to be associated with increased liver disease risk, such as CTLA-4, IL-18, transmembrane 6 superfamily member 2 and GSTM1 [64-66]. Besides, more and more studies have indicated IL- 6 and IL-10 polymorphisms may be associated with CL risk. Due to the limited number of samples about each study, the conclusion for every study may not be credible. Yao et al. found that IL-10 rs1800896 polymorphism was

Table 3 Publication bias tests (Begg's funnel plot and Egger's test for publication bias test) for IL-10 -592 polymorphism

\begin{tabular}{llllllll}
\hline Egger's test & \multicolumn{3}{c}{} & \multicolumn{3}{c}{ Begg's test } \\
\hline Genetic type & Coefficient & Standard error & $\mathrm{t}$ & $P$ value & $95 \%$ Cl of intercept & $z$ & $P$ value \\
C-allele vs. A-allele & -0.181 & 1.211 & -0.15 & 0.883 & $(-2.736-2.374)$ & 1.26 & 0.208 \\
CA vs. AA & -0.047 & 0.447 & -0.11 & 0.917 & $(-0.992-0.897)$ & 0.35 & 0.726 \\
CC + CA vs. AA & -0.047 & 0.51 & -0.09 & 0.927 & $(-1.124-1.029)$ & 0.56 & 0.576 \\
\hline
\end{tabular}




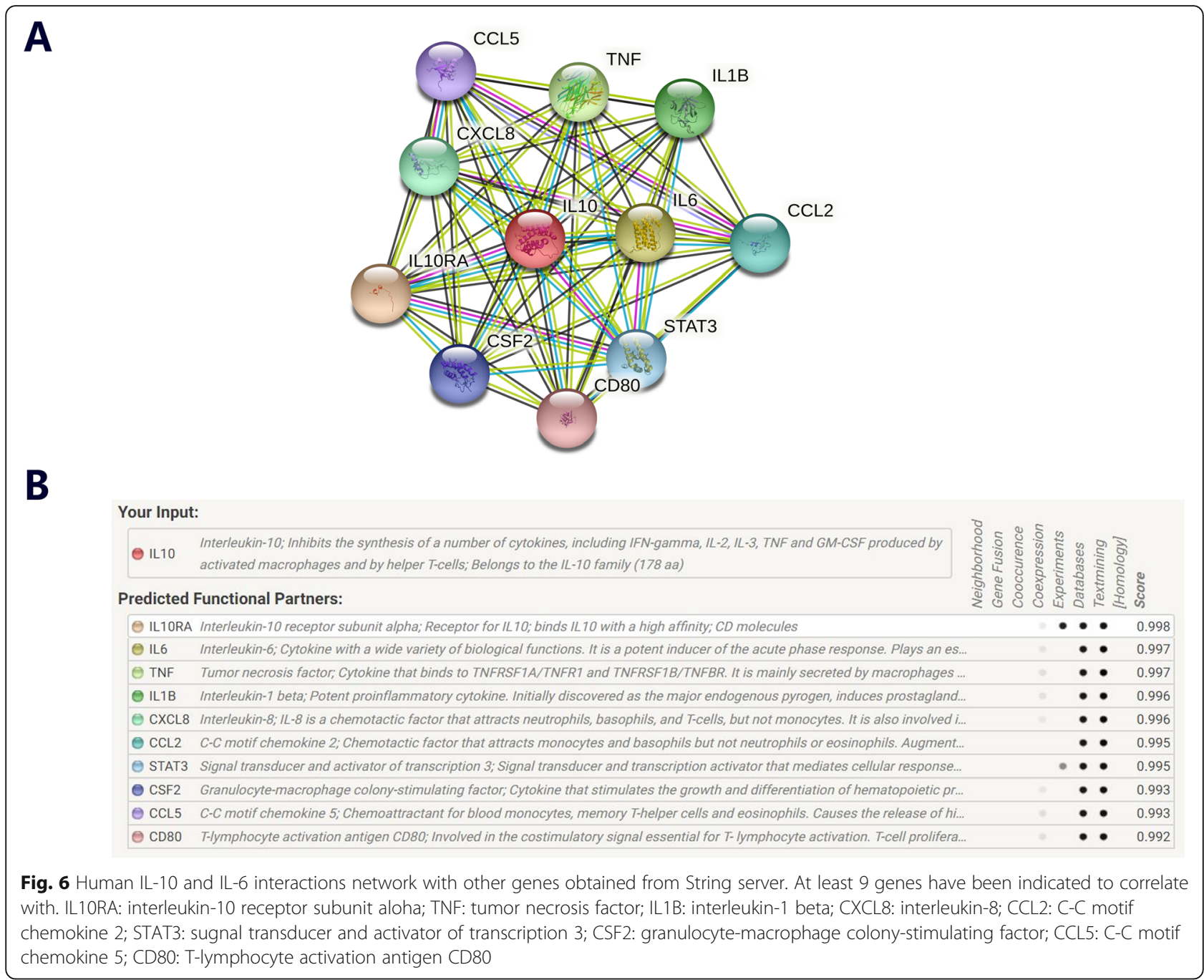

correlated with an increased risk of CL, especially in individuals with chronic hepatitis B [46]. Falleti et al. polymorphisms of IL-6 were associated with hepatocellular carcinoma (HCC) occurrence among patients with CL [34]. It is necessary to combine all previous studies and increase the sample size, we wish to obtain comprehensive and convince conclusions between IL- 6 or IL-10 polymorphism and CL susceptibility.

It is in time to analyze the association between IL-6 and IL-10 polymorphisms and CL risk using metaanalysis method. After our searching through main database, 19 different case-control studies were identified for IL-10 polymorphism, and 9 case-control studies were detected for IL- 6 polymorphism. The main results about current study are that IL-10 -592 polymorphism was a risk factor for CL risk in the whole samples, especially in Asian population, moreover, IL-10 - 1082 polymorphism had an increased association for PBC, which may offer references for early detection, prevention and treatment about CL. No positive results were observed in other polymorphisms, which due to the sample size and publication bias.

We all know the development and outcome about CL is complex and multi-factorial. Focusing on only each gene or each polymorphism is limited. Hence, we try our best to detect other potential genes related with $\mathrm{CL}$ based on online String server. Other nine most possible genes and current two related genes were shown in the network. Among them, six genes belong to cytokine family, and these scores were all in the front, the first related genes are IL-10RA, which is the receptor of IL-10 gene. Hennig et al. indicated IL-10RA gene polymorphisms may play a modulatory role in the outcome (including severity of fibrosis and overall inflammation) of hepatitis $C$ infection [67]. Galal et al. confirmed that TNF family lymphotoxin-alpha GG genotype and low platelet count were independent predictors for $\mathrm{HCC}$ 
development in patients with HCV-LC [68]. AmirpourRostami et al. summarized the main correlation between the polymorphisms within IL-18 and IL-1B genes and chronic hepatitis B [69]. In a word, we should deep explore these partners of IL-10 and 6 genes, and gene-gene interactions in the development and treatment for CL in the next step.

There are some limitations should be paid attention. At the beginning, further studies should focus on Mixed and African populations, which was vacant in current analysis and need many more studies. Second, because $\mathrm{CL}$ is a multi-factors disease, gene-gene and geneenvironment interactions should be considered and brought in. It is possible that specific environmental and lifestyle factors influence the associations between IL-10 and IL-6 polymorphism and CL, including age, sex, diet, smoking, familial history, parasite history, virus and immune factors. Third, whether the CL patients within other complications, such as abnormal liver function, HCC and hepatitis, all the included factors have not been reported. Further comprehensive studies should include above items. Fourth, the stage of CL is not distinguished, which should be analyzed separately (compensatory and decompensated period) and can be more accurate for prediction and treatment.

\section{Conclusions}

Our present meta-analysis suggests that IL-10 -592 and - 1082 polymorphisms may be associated with CL risk, which may be proofed in following larger and comprehensive studies.

\section{Abbreviations}

CL: cirrhosis of liver; LC: Liver cirrhosis; HWE: Hardy-Weinberg equilibrium; OR: Odds ratio; 95\%Cl: 95\% Confidence interval; PBC: primary biliary cirrhosis; ALC: alcoholic liver cirrhosis

\section{Acknowledgements}

Not applicable.

\section{Availability of data and material}

All data generated or analyzed in this study are included in this published article and its supplementary information files.

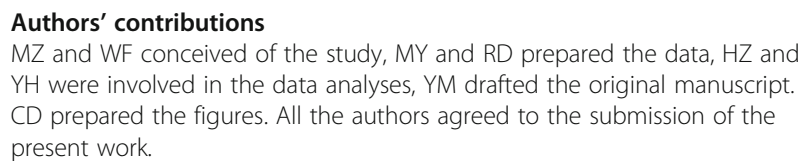
$\mathrm{YH}$ were involved in the data analyses, YM drafted the original manuscript. $\mathrm{CD}$ prepared the figures. All the authors agreed to the submission of the present work.

\section{Funding}

This work was supported by Guangdong Basic and Applied Basic Research Foundation, China (2019A1515011646), National Natural Science Foundation of China (81401689), Guangzhou Science and Technology Plan Project (202102080298), Yat-sen Sailing Research Funds of Sun Yat-sen Memorial Hospital of Sun Yat-sen University, China (YXQH202004) and Guangdong Basic and Applied Basic Research Foundation, China (2019A1515011646, 2016A020219004). The authors have no conflicts of interest to declare in relation to this article.

\section{Declarations}

Ethics approval and consent to participate

Not applicable.

\section{Consent for publication}

Not applicable.

\section{Competing interests}

The authors proclaim that they have no competing interests.

\section{Author details}

${ }^{1}$ Department of Clinical Laboratory, Sun Yat-sen Memorial Hospital of Sun Yat-sen University, Guangzhou 510120, China. ${ }^{2}$ Guangdong Provincial Key Laboratory of Malignant Tumor Epigenetics and Gene Regulation, Sun Yat-sen Memorial Hospital of Sun Yat-sen University, Guangzhou 510120, China. ${ }^{3}$ Emergency Department, Sun Yat-Sen Memorial Hospital, Sun Yat-Sen University, Guangzhou, People's Republic of China. ${ }^{4}$ Department of Parasitology, Zhongshan School of Medicine, Sun Yat-sen University, Guangzhou, Guangdong 510080, People's Republic of China. ${ }^{5}$ Key Laboratory of Tropical Disease Control (Sun Yat-sen University), Chinese Ministry of Education, Guangzhou, Guangdong 510080, People's Republic of China. ${ }^{6}$ Department of Urology, Affiliated Hospital of Jiangnan University, 1000 Hefeng Rd, Wuxi 214000, People's Republic of China.

Received: 29 June 2021 Accepted: 23 November 2021

Published online: 09 December 2021

\section{References}

1. Fallowfield JA, Jimenez-Ramos M, Robertson A. Emerging synthetic drugs for the treatment of liver cirrhosis. Expert Opin Emerg Drugs. 2021:1-16. https://doi.org/10.1080/14728214.2021.2009799.

2. Asrani SK, Devarbhavi H, Eaton J, Kamath PS. Burden of liver diseases in the world. J Hepatol. 2019;70(1):151-71. https://doi.org/10.1016/j.jhep.2018.09. 014.

3. Sepanlou SG, Safiri S, Bisignano C, Collaborator GC. The global, regional, and national burden of cirrhosis by cause in 195 countries and territories, 19902017: a systematic analysis for the global burden of disease study. Lancet Gastroenterol Hepatol 2020. 2017;5(3):245-66.

4. Scaglione S, Kliethermes S, Cao G, Shoham D, Durazo R, Luke A, et al. The epidemiology of cirrhosis in the United States: a population-based study. J Clin Gastroenterol. 2015;49(8):690-6. https://doi.org/10.1097/MCG. 0000000000000208

5. Hsiang JC, Bai WW, Raos Z, Stableforth W, Upton A, Selvaratnam S, et al. Epidemiology, disease burden and outcomes of cirrhosis in a large secondary care hospital in South Auckland, New Zealand. Intern Med J. 2015;45(2):160-9. https://doi.org/10.1111/imj.12624.

6. Collaborators. GDallaP: Global, regional, and national incidence, prevalence, and years lived with disability for 354 diseases and injuries for 195 countries and territories, 1990-2017: a systematic analysis for the global burden of disease study 2017. Lancet (London, England) 2018, 392(10159):1789-1858.

7. $\mathrm{Xu} J \mathrm{H}, \mathrm{Yu} Y \mathrm{Y}, \mathrm{Xu} \mathrm{XY}$. [research progress and prospect of liver cirrhosis]. Zhonghua Gan zang bing za zhi = Zhonghua ganzangbing zazhi $=$. Chin J Hepatol. 2021;29(2):108-10. https://doi.org/10.3760/cma.j.cn501113-202101 02-00002.

8. Paik JM, Golabi P, Younossi Y, Mishra A, Younossi ZM. Changes in the Global Burden of Chronic Liver Diseases From 2012 To 2017: the growing impact of NAFLD. Hepatol (Baltimore, Md). 2020;72(5):1605-16.

9. Estes C, Razavi H, Loomba R, Younossi Z, Sanyal AJ. Modeling the epidemic of nonalcoholic fatty liver disease demonstrates an exponential increase in burden of disease. Hepatol (Baltimore, Md). 2018:67(1):123-33.

10. Danis VA, Millington M, Hyland VJ, Grennan D. Cytokine production by normal human monocytes: inter-subject variation and relationship to an IL1 receptor antagonist (IL-1Ra) gene polymorphism. Clin Exp Immunol. 1995; 99(2):303-10. https://doi.org/10.1111/j.1365-2249.1995.tb05549.x.

11. Motavaf M, Safari S, Alavian SM. Interleukin 18 gene promoter polymorphisms and susceptibility to chronic hepatitis B infection: a review study. Hepat Mon. 2014;14(7):e19879. 
12. Pestka S, Krause CD, Sarkar D, Walter MR, Shi Y, Fisher PB. Interleukin-10 and related cytokines and receptors. Annu Rev Immunol. 2004;22(1):929-79. https://doi.org/10.1146/annurev.immunol.22.012703.104622.

13. Eskdale J, Keijsers V, Huizinga T, Gallagher G. Microsatellite alleles and single nucleotide polymorphisms (SNP) combine to form four major haplotype families at the human interleukin-10 (IL-10) locus. Genes Immun. 1999;1(2): 151-5. https://doi.org/10.1038/sj.gene.6363656.

14. Ishihara K, Hirano T. IL-6 in autoimmune disease and chronic inflammatory proliferative disease. Cytokine Growth Factor Rev. 2002;13(4-5):357-68. https://doi.org/10.1016/S1359-6101(02)00027-8.

15. Motawi T, Shaker OG, Hussein RM, Houssen M. Polymorphisms of a1antitrypsin and Interleukin- 6 genes and the progression of hepatic cirrhosis in patients with a hepatitis C virus infection. Balkan J Med Genet BJMG. 2016;19(2):35-44. https://doi.org/10.1515/bjmg-2016-0034.

16. Zhu H, Yu L, Feng L. Association of apolipoprotein B Xbal (rs693) polymorphism and gallstone disease risk based on a comprehensive analysis. Genes Environ Off J Japan Environ Mutagen Soc. 2021;43(1):17. https://doi.org/10.1186/s41021-021-00189-z.

17. Ren $K$, Ruan $Y$, Tang J, Jiang X, Sun H, Nong L, et al. Association of ADAM12 gene polymorphisms with knee osteoarthritis susceptibility. Oncotarget. 2017;8(44):77710-21. https://doi.org/10.18632/oncotarget.20772.

18. Ren K, Tang J, Nong L, Shen N, Li X: Association between interleukin-21 gene rs6822844 polymorphism and rheumatoid arthritis susceptibility. Biosci Rep 2019, 39(8), 39, 8, https://doi.org/10.1042/BSR20190110.

19. Higgins JP, Thompson SG. Quantifying heterogeneity in a meta-analysis. Stat Med. 2002;21(11):1539-58. https://doi.org/10.1002/sim.1186.

20. Cheng JW, Cheng SW, Ma XY, Cai JP, Li Y, Lu GC, et al. Myocilin polymorphisms and primary open-angle glaucoma: a systematic review and meta-analysis. PLoS ONE. 2012;7(9):e46632. https://doi.org/10.1371/journal. pone.0046632.

21. Zeng T, Guo FF, Zhang CL, Song FY, Zhao XL, Xie KQ. Roles of cytochrome P4502E1 gene polymorphisms and the risks of alcoholic liver disease: a meta-analysis. PLoS ONE. 2013;8(1):e54188. https://doi.org/10.1371/journal. pone.0054188

22. Higgins JP, Thompson SG, Deeks JJ, Altman DG. Measuring inconsistency in meta-analyses. BMJ (Clin Res ed). 2003;327(7414):557-60. https://doi.org/1 0.1136/bmj.327.7414.557

23. DerSimonian R, Laird N. Meta-analysis in clinical trials. Control Clin Trials. 1986;7(3):177-88. https://doi.org/10.1016/0197-2456(86)90046-2.

24. Mantel N, Haenszel W. Statistical aspects of the analysis of data from retrospective studies of disease. J Natl Cancer Inst. 1959;22(4):719-48.

25. Mohammadi A, Azarnezhad A, Khanbabaei H, Izadpanah E, Abdollahzadeh $R$, Barreto $G E$, et al. Vitamin D receptor genetic polymorphisms and the risk of multiple sclerosis: a systematic review and meta-analysis. Steroids. 2020; 158:108615. https://doi.org/10.1016/j.steroids.2020.108615.

26. Napolioni $\mathrm{V}$. The relevance of checking population allele frequencies and Hardy-Weinberg Equilibrium in genetic association studies: the case of SLC6A4 5-HTTLPR polymorphism in a Chinese Han Irritable Bowel Syndrome association study. Immunol Lett. 2014;162(1 Pt A):276-8.

27. Hayashino Y, Noguchi Y, Fukui T. Systematic evaluation and comparison of statistical tests for publication bias. J Epidemiol. 2005;15(6):235-43. https:// doi.org/10.2188/jea.15.235.

28. Shao HB, Ren K, Gao SL, Zou JG, Mi YY, Zhang LF, et al. Human methionine synthase A2756G polymorphism increases susceptibility to prostate cancer. Aging. 2018:10(7):1776-88. https://doi.org/10.18632/aging.101509.

29. Park BL, Lee HS, Kim YJ, Kim JY, Jung JH, Kim LH, et al. Association between interleukin 6 promoter variants and chronic hepatitis B progression. Exp Mol Med. 2003;35(2):76-82. https://doi.org/10.1038/emm.2003.11.

30. Marcos M, Pastor I, González-Sarmiento R, Laso FJ. Common polymorphisms in interleukin genes (IL4, IL6, IL8 and IL12) are not associated with alcoholic liver disease or alcoholism in Spanish men. Cytokine. 2009;45(3):158-61. https://doi.org/10.1016/j.cyto.2008.11.003.

31. Fan $L Y$, Zhu Y, Zhong $R Q$, Tu $X Q$, Ye WM, Chen $Q B$, et al. Genetic association between interleukins gene polymorphisms with primary biliary cirrhosis in Chinese population. Acta Acad Med Sin. 2004;5(26):505-10.

32. Giannitrapani L, Soresi M, Giacalone A, Campagna ME, Marasà M, Cervello M, et al. IL-6 -174G/C polymorphism and IL-6 serum levels in patients with liver cirrhosis and hepatocellular carcinoma. Omics : a J integr Biol. 2011; 15(3):183-6. https://doi.org/10.1089/omi.2010.0093.

33. Saxena R, Chawla YK, Verma I, Kaur J. IL-6(-572/-597) polymorphism and expression in HBV disease chronicity in an Indian population. Am J Hum
Biol Off J Hum Biol Counc. 2014;26(4):549-55. https://doi.org/10.1002/a jhb.22562.

34. Falleti E, Fabris C, Toniutto P, Fontanini E, Cussigh A, Bitetto D, et al. Interleukin-6 polymorphisms and gender: relationship with the occurrence of hepatocellular carcinoma in patients with end-stage liver disease. Oncology. 2009;77(5):304-13. https://doi.org/10.1159/ 000260057

35. Abd El-Baky RM, Hetta HF, Koneru G, Ammar M, Shafik EA, Mohareb DA, et al. Impact of interleukin IL-6 rs-1474347 and IL-10 rs-1800896 genetic polymorphisms on the susceptibility of HCV-infected Egyptian patients to hepatocellular carcinoma. Immunol Res. 2020;68(3):118-25. https://doi.org/1 0.1007/s12026-020-09126-8.

36. Barooah P, Saikia S, Kalita MJ, Bharadwaj R, Sarmah P, Bhattacharyya M, et al. IL-10 polymorphisms and haplotypes predict susceptibility to hepatocellular carcinoma occurrence in patients with hepatitis $C$ virus infection from Northeast India. Viral Immunol. 2020;33(6):457-67. https://doi.org/10.1089/ vim.2019.0170.

37. Bathgate AJ, Pravica V, Perrey C, Hayes PC, Hutchinson IV. Polymorphisms in tumour necrosis factor alpha, interleukin-10 and transforming growth factor beta1 genes and end-stage liver disease. Eur J Gastroenterol Hepatol. 2000; 12(12):1329-33. https://doi.org/10.1097/00042737-200012120-00011.

38. Cao LN, Cheng SL, Liu W: IL10 rs 1800896 polymorphism is associated with liver cirrhosis and chronic hepatitis B. Genet Mol Res GMR 2016, 15(1), 15, 1, https://doi.org/10.4238/gmr.15017256.

39. Cheong JY, Cho SW, Hwang IL, Yoon SK, Lee JH, Park CS, et al. Association between chronic hepatitis B virus infection and interleukin10, tumor necrosis factor-alpha gene promoter polymorphisms. J Gastroenterol Hepatol. 2006;21(7):1163-9. https://doi.org/10.1111/j.1440-1 746.2006.04304.x

40. Corchado S, Márquez M. Montes de Oca M, Romero-cores P, Fernández Gutiérrez C, Girón-González JA: influence of genetic polymorphisms of tumor necrosis factor alpha and interleukin 10 genes on the risk of liver cirrhosis in HIV-HCV Coinfected patients. PLoS ONE. 2013;8(6):e66619. https://doi.org/10.1371/journal.pone.0066619.

41. Liu Y, Yu MC, Zhang AQ, Wang YB, Jiang K, Dong JH. Interleukin-10 gene promoter polymorphism and risk of liver cirrhosis. Genet Mol Res GMR. 2015;14(1):1229-34. https://doi.org/10.4238/2015.February.13.1.

42. Marcos M, Pastor I, González-Sarmiento R, Laso FJ. Interleukin-10 gene polymorphism is associated with alcoholism but not with alcoholic liver disease. Alcohol Alcohol (Oxford, Oxfordshire). 2008;43(5):523-8.

43. Matsushita M, Tanaka A, Kikuchi K, Kitazawa E, Kawaguchi N, Kawashima Y, et al. Association of single nucleotide polymorphisms of the interleukin-10 promoter gene and susceptibility to primary biliary cirrhosis: immunogenetic differences in Italian and Japanese patients. Autoimmunity, 2002:35(8):531-6. https://doi.org/10.1080/0891693021000056703.

44. Sheneef A, Esmat MM, Mohammad AN, Mahmoud AA, Moghazy HM, Noureldin AK. Interleukin-10 and interferon gamma gene polymorphisms and hepatitis C virus-related liver cirrhosis risk. J interferon \& Cytokine Res Off J Int Soc Interferon Cytokine Res. 2017;37(4):175-80. https://doi.org/10.1 089/jir.2016.0106.

45. Yang AM, Wen LL, Yang CS, Wang SC, Chen CS, Bair MJ. Interleukin 10 promoter haplotype is associated with alcoholic liver cirrhosis in Taiwanese patients. Kaohsiung J Med Sci. 2014;30(6):291-8. https://doi.org/10.1016/j. kjms.2014.02.016.

46. Yao L, Xing S, Fu X, Song H, Wang Z, Tang J, et al. Association between interleukin-10 gene promoter polymorphisms and susceptibility to liver cirrhosis. Int J Clin Exp Pathol. 2015;8(9):11680-4.

47. Zappala F, Grove J, Watt FE, Daly AK, Day CP, Bassendine MF, et al. No evidence for involvement of the interleukin-10 -592 promoter polymorphism in genetic susceptibility to primary biliary cirrhosis. J Hepatol. 1998;28(5):820-3. https://doi.org/10.1016/S0168-82 78(98)80232-8

48. Chen $Q B$, Fan $L Y$, Zhong RQ, Tu XQ, Yuan $Y$, Zhu Y, et al. A study on the relationship between interleukin-10 promoter polymorphism and qutoimmune liver disease. Chin J Hepatol. 2004;12(6):356-9.

49. Ghaleh Baghi S, Alavian SM, Mehrnoush L, Salimi S. Impact of the IL-10 promoter gene polymorphisms in the severity of chronic hepatitis B infection. Hepat Mon. 2015;15(7):e28287. https://doi.org/10.5812/hepa tmon.28287v2.

50. Jiang ZL, Zhang W, Zhang H, Liu YB, Su SB. Relationship between TNF-a, TGF- $\beta 1$ and IL-10 genetic polymorphisms and post-hepatitis B cirrhosis. 
World Chin J Digestology. 2009;17(31):3263-8. https://doi.org/10.11569/ wcjd.v17.i31.3263.

51. Khalifa AS, Jaiash DA, Shady AM, El-saeed GK, Ghonaim MM, Makled AA, et al. Interleukins-10 and 18 genes polymorphisms in hepatitis B virus infected Saudi patients. Res J Immunol. 2016;9(1):1-8.

52. Moreira ST, Silva GF, de Moraes CF. Grotto RM, de Moura Campos Pardini Ml, Bicalho Mda G, Moliterno RA: influence of cytokine and cytokine receptor gene polymorphisms on the degree of liver damage in patients with chronic hepatitis C. meta gene. 2016;9:90-6. https://doi.org/10.1016/j. mgene.2016.04.003.

53. Tang S, Liu Z, Zhang Y, He Y, Pan D, Liu Y, et al. Rather than Rs 1800796 polymorphism, expression of interleukin-6 is associated with disease progression of chronic HBV infection in a Chinese Han population. Dis Markers. 2013;35(6):799-805. https://doi.org/10.1155/2013/508023.

54. Wang SY, Sun SL, Ma WM, Zheng Q, Liu HZ. Relationship between live cirrhosis and interleukin-10 promoter polymorphisms in chronic hepatitis B patients. Innunological J. 2010;26(8):694-7.

55. Wu JX, Jia YT. Association analysis of interleukin-10 gene promoter polymorphisms with hepatitis B virus infection consequence. ChinJ Integr Tradit Western Med Liver Dis. 2010;20(5):262-6.

56. Jepsen P, Younossi ZM. The global burden of cirrhosis: a review of disabilityadjusted life-years lost and unmet needs. J Hepatol. 2021;75(Suppl 1):S3s13. https://doi.org/10.1016/j.jhep.2020.11.042.

57. Schuppan D, Afdhal NH. Liver cirrhosis. Lancet (London, England). 2008; 371(9615):838-51.

58. Younossi ZM, Guyatt G, Kiwi M, Boparai N, King D. Development of a disease specific questionnaire to measure health related quality of life in patients with chronic liver disease. Gut. 1999;45(2):295-300. https://doi.org/1 0.1136/gut.45.2.295.

59. Rabiee A, Ximenes RO, Nikayin S, Hickner A, Juthani P, Rosen RH, et al. Factors associated with health-related quality of life in patients with cirrhosis: a systematic review. Liver Int Off J Int Assoc Study Liver. 2021;41(1): 6-15. https://doi.org/10.1111/liv.14680.

60. Loria A, Escheik C, Gerber NL, Younossi ZM. Quality of life in cirrhosis. Curr Gastroenterol Rep. 2013;15(1):301. https://doi.org/10.1007/s11894012-0301-5.

61. Younossi ZM, Stepanova M, Afdhal N, Kowdley KV, Zeuzem S, Henry L, et al. Improvement of health-related quality of life and work productivity in chronic hepatitis $\mathrm{C}$ patients with early and advanced fibrosis treated with ledipasvir and sofosbuvir. J Hepatol. 2015;63(2):337-45. https://doi.org/10.1 016/j.jhep.2015.03.014.

62. Younossi ZM, Stepanova M, Nader F, Lam B, Hunt S. The patient's journey with chronic hepatitis $C$ from interferon plus ribavirin to interferon- and ribavirin-free regimens: a study of health-related quality of life. Aliment Pharmacol Ther. 2015;42(3):286-95. https://doi.org/10.1111/apt.13269.

63. Younossi ZM, Stepanova M, Lawitz EJ, Reddy KR, Wai-Sun Wong V, Mangia A, et al. Patients with nonalcoholic steatohepatitis experience severe impairment of health-related quality of life. Am J Gastroenterol. 2019; 114(10):1636-41. https://doi.org/10.14309/ajg.0000000000000375.

64. Zhang S, Yang X, Wang W. Associations of genetic polymorphisms in CTLA-4 and IL-18 with chronic liver diseases: evidence from a metaanalysis. Genomics. 2020;112(2):1889-96. https://doi.org/10.1016/j.ygeno.2 019.11.001.

65. Gu Y, Zhao J, Ao L, Ma J, Bao K, Liu M, et al. The influence of polymorphic GSTM1 gene on the increased susceptibility of non-viral hepatic cirrhosis: evidence from observational studies. Eur J Med Res. 2018;23(1):34. https:// doi.org/10.1186/s40001-018-0331-z.

66. Chen X, Zhou P, De L, Li B, Su S. The roles of transmembrane 6 superfamily member 2 rs58542926 polymorphism in chronic liver disease: a metaanalysis of 24,147 subjects. Mol Genet Genom Med. 2019;7(8):e824.

67. Hennig BJ, Frodsham AJ, Hellier S, Knapp S, Yee L, Wright M, et al. Influence of IL-10RA and IL-22 polymorphisms on outcome of hepatitis C virus infection. Liver Int Off J Int Assoc Study Liver. 2007;27(8):1134-43. https://doi.org/10.1111/j.1478-3231.2007.01518.x.

68. Galal G, Tammam H, Abdel Aal A, Fahmy N, Sheneef A, Ahmed N, et al. Role of Lymphotoxin-a gene polymorphism in hepatitis $C$ virus-related chronic liver disorders. Infect drug Resist. 2021;14:1921-30. https://doi.org/10.2147/ IDR.S306879.

69. Amirpour-Rostami S, Kazemi Arababadi M. IL-18 and IL-1ß gene polymorphisms: the plausible risk factors for chronic hepatitis B. Viral Immunol. 2019;32(5):208-13. https://doi.org/10.1089/vim.2018.0155.

\section{Publisher's Note}

Springer Nature remains neutral with regard to jurisdictional claims in published maps and institutional affiliations.
Ready to submit your research? Choose BMC and benefit from:

- fast, convenient online submission

- thorough peer review by experienced researchers in your field

- rapid publication on acceptance

- support for research data, including large and complex data types

- gold Open Access which fosters wider collaboration and increased citations

- maximum visibility for your research: over $100 \mathrm{M}$ website views per year

At BMC, research is always in progress.

Learn more biomedcentral.com/submissions 